\title{
PEMANFAATAN TEPUNG SINGKONG SEBAGAI SUBSTITUSI TERIGU UNTUK VARIASI CAKE
}

\author{
Risa Panti Ariani ${ }^{1}$, I.A.P Hemy Ekayani ${ }^{2}$, Luh Masdarini ${ }^{3}$ \\ 1, 2, 3 Jurusan Pendidikan Kesejahteraan Keluarga \\ Universitas Pendidikan Ganesha \\ Singaraja, Bali, Indonesia \\ e-mail:rp_ariani@yahoo.co.id
}

\begin{abstract}
Abstrak
Tujuan penelitian ini untuk memperoleh variasi cake dari tepung singkong dengan mensubstitusi terigu. Karena terigu merupakan produk impor olahan dari gandum, sebagai usaha mendukung peningkatan ketahanan pangan. Penelitian ini menggunakan metode penelitian eksperimental semu di laboratorium karena keterbatasan untuk mengontrol semua variabel yang relevan. Instrumen pengumpulan data menggunakan lembar observasi untuk memperoleh data uji kualitas dari panelis terlatih, sedangkan data uji selera diperoleh dari masyarakat umum untuk mengetahui keberterimaan variasi cake singkong. Analisis data penelitian dilakukan secara deskriptif kualitatif. Hasil penelitian memperoleh kualitas cake singkong pada kriteria yang sempurna pada, (a) pound cake dengan substitusi $80 \%$ bahan utama, (b) roll cake dengan substitusi $100 \%$ bahan utama, tetapi kualitas tekstur terendah, (c) chiffon cake dengan substitusi $100 \%$ bahan utama, serta pengembangan (volume) maksimal, (d) bolu kukus dengan substitusi $80 \%$ bahan utama, tetapi kualitas aroma terendah, (e) sponge cake dengan substitusi $80 \%$ bahan utama, tetapi semua kriteria terendah, (f) brownies dengan substitusi $100 \%$ bahan utama, serta semua kriteria tertinggi, (g) fruit cake menggunakan buah-buahan lokal dengan substitusi $100 \%$ bahan utama, serta semua kriteria tertinggi, dan (g) rainbow cake dengan substitusi $100 \%$ bahan utama, tetapi kualitas tekstur terendah. Secara umum keberterimaan masyarakat sangat menyukai variasi cake singkong, tetapi sponge cake dan rainbow cake memperoleh keberterimaan terendah. Dengan demikian 8 jenis cake dapat menggunakan tepung singkong sebagai substitusi terigu untuk mendukung peningkatan ketahanan pangan.
\end{abstract}

Kata kunci: tepung singkong, variasi cake, substitusi terigu

\begin{abstract}
The purpose of this study to obtain a cake variation of substituting wheat with cassava flour. Because wheat is imported products processed from wheat, in an effort to support increased food security. This study uses a quasi-experimental research in the laboratory because of the limitations to control all the relevant variables. Data collection instrument uses observation sheets to obtain quality test data from trained research, while the taste test data obtained from the general public to determine the acceptability of variation cassava cake. The data analysis was conducted by qualitative descriptive study. Research results obtained quality cake cassava on the criteria perfectly on, (a) pound cake with a substitution of $80 \%$
\end{abstract}


of the main ingredient, (b) roll cake with substitution of $100 \%$ main ingredient, but the quality of the texture of the lowest, (c) chiffon cake with substitution of $100 \%$ the main ingredient, and development (volume) maximum, (d) steamed sponge with the substitution of $80 \%$ of the main ingredient, but the quality of the aroma room, (e) sponge cake with a substitution of $80 \%$ of the main ingredient, but all the criteria lows, (f) brownies with substitution $100 \%$ main ingredient, as well as all the supreme criterion, $(\mathrm{g})$ fruit cake using local fruits by substitution of $100 \%$ main ingredient, as well as all the supreme criterion, and (g) rainbow cake by substituting $100 \%$ main ingredient, but the texture quality lowest. In general acceptability of the community is like the variety of cassava cake, but the cake and rainbow sponge cake obtain the lowest acceptance. Thus the 8 types of cake can be used as a substitution of cassava flour wheat to support increased food security.

Keywords: cassava flour, cake variation, substitution wheat

\section{PENDAHULUAN}

Ketahanan pangan di Indonesia terdapat dalam Undang-undang nomor 7 tahun 1996 tentang usaha mewujudkan ketersediaan pangan bagi seluruh rumah tangga, dalam jumlah yang cukup, mutu dan gizi yang layak, aman dikonsumsi, merata serta terjangkau oleh setiap individu. Masyarakat di Indonesia terutama generasi muda lebih menyukai mengkonsumsi berbagai makanan yang menggunakan bahan pangan dari tepung terigu, seperti mie, roti, cake dan berbagai makanan lainnya. Dari pengamatan peneliti, generasi muda saat ini, bahkan anak-anak diperkotaan hampir setiap hari mengkonsumsi mie atau roti. Tingginya keinginan untuk mengkonsumsi makanan-makanan tersebut lebih disebabkan karena rasanya yang enak, harga terjangkau, mudah diperoleh dan pengaruh dari berbagai iklan di media cetak/elektronik. Selain itu karena kesibukan orang tua, maka lebih mudah bagi orang tua untuk menyiapkan makanan yang praktis pengolahannya, dan disukai anakanaknya.

Gandum serta produk olahannya seperti terigu, saat ini sebagai bahan pangan impor telah memasuki segala aspek kehidupan setiap lapisan masyarakat di Indonesia dalam kurang lebih empat dekade terakhir. Ketika program diversifikasi pangan berbasis produk lokal berhenti, pangan berbasis terigu terus meningkat. Saat ini Konsumsi gandum Indonesia per tahun $21 \mathrm{~kg} / \mathrm{kapita}$, terbesar kedua setelah beras. Tepung terigu merupakan olahan dari gandum yang tidak dibudidayakan di Indonesia. Gandum merupakan bahan makanan impor terbesar yang dikonsumsi masyarakat Indonesia setiap hari, bahkan sudah menggeser konsumsi makanan berbahan baku lokal seperti beras dan umbi-umbian. Menurut berita dari Agrobusiness, Daily News (2013), berdasarkan data Badan Pusat Statistik (BPS) beberapa komoditas bahan makanan yang selalu diimpor, seperti dalam tabel berikut: 
Tabel 1. Komoditas bahan makanan yang diimpor tahun 2012

\begin{tabular}{|c|c|c|}
\hline No & Nama Komoditas & Impor / Tahun \\
\hline 1 & Gandum & 6,3 juta ton \\
\hline 2 & Garam & 2.2 juta ton \\
\hline 3 & Kedelai & 1.9 juta ton \\
\hline 4 & Beras & 1,8 juta ton \\
\hline 5 & Jagung & 1,7 juta ton \\
\hline 6 & Tepung terigu & 479.7 ribu ton \\
\hline 7 & Gula pasir & 91.1 ribu ton \\
\hline 8 & Singkong & 13.3 ribu ton \\
\hline
\end{tabular}

Sumber: diolah dari berbagai data, 2014

Singkong atau ubi kayu atau
cassava (Monihot esculenta)
merupakan pilihan yang tepat untuk tahap awal, karena bisa dijadikan jawaban untuk pemenuhan kebutuhan tepung di Indonesia. Dua jenis ubi ini sangat mudah ditanam di wilayah indonesia, mempunyai produktifitas yang cukup tinggi, pemeliharaannya tidak mahal, dan harga pokok produksinya cukup rendah, serta tepung yang dihasilkan mempunyai karakteristik yang baik, serta nilai gizinya yang cukup baik. Teknologi pengolahan singkong menjadi tepung sangat sederhana dan murah. Dengan teknologi itu, usaha skala kecil-menengah mampu menghasilkan tepung dengan kualitas yang tidak kalah bagus dibandingkan tepung terigu yang diproduksi perusahaan besar.

Upaya diversifikasi pangan dengan memanfaatkan singkong sebagai substitusi terigu merupakan alternative mengurangi ketergantungan terhadap tepung terigu sebagai produk impor. Bahkan kandungan karbohidrat yang rendah menjadikan cake singkong hidangan sehat dengan kalori rendah. Disamping itu secara ekonomi juga dapat memberikan dampak pada peningkatan pendapatan para petani singkong. Tetapi sangat penting dukungan dari pemerintahan dan masyarakat untuk menyukseskan program diversifikasi pangan ini.

Berdasarkan SUSENAS tahun 2010, 2011, 2012 dan 2013, umbiumbian belum dimanfaatkan secara optimal, bahkan setiap tahun terjadi penurunan konsumsi umbi-umbian. Untuk mengurangi ketergantungan terhadap tepung terigu, maka diperlukan upaya diversifikasi pangan dengan cara memanfaatkan singkong menjadi tepung. Karena singkong merupakan salah satu bahan makanan sumber karbohidrat yang mudah didapat dengan harga terjangkau, tetapi memiliki masa simpan yang singkat selama 2-3 hari, kemudian rusak. Tepung singkong adalah hasil olah dari singkong yang dibuat menjadi cacah, kemudian dihaluskan dan disaring sehingga menghasilkan tepung singkong yang halus. Cacah adalah makanan pokok tradisional masyarakat di Buleleng yang dibuat dari singkong digobed (parut kasar) yang kering. Dari hasil penelitian sebelumnya (Risa, 2011) tepung umbiumbian dapat diolah menjadi berbagai makanan seperti dodol, kue kering, mie, opak dan krupuk. 
Singkong merupakan umbiumbian yang memiliki karakteristik mendekati terigu, tetapi kandungan kalori pada singkong jauh lebih rendah dari tepung terigu. Singkong mengandung 146 kalori per 100 gr, sedangkan tepung terigu mengandung 365 kalori per 100 gr. (Daftar Komposisi Bahan Makanan, 1989). Kandungan protein pada singkong rendah, sehingga diharapkan mampu menggantikan tepung terigu dengan kandungan protein rendah untuk berbagai jenis cake.

Permasalahannya berbagai jenis cake menggunakan tepung terigu sebagai bahan utama, meskipun beberapa cake mengurangi sedikit bahan utama dan menggantikannya dengan sedikit umbi-umbian segar. Melalui penelitian ini, diharapkan dapat mensubstitusi $100 \%$ terigu dengan tepung singkong sebagai bahan utama untuk membuat berbagai variasi cake. Untuk itu perlu penelitian tentang diversifikasi tepung singkong sebagai substitusi terigu untuk variasi cake yang berkualitas.

\section{METODE}

Penelitian ini merupakan penelitian eksperimen semu guna memperoleh optimalisasi penggunaan bahan utama tepung umbi-umbian sebagai substitusi terigu dalam variasi cake dengan perlakuan yang dirancang peneliti. Variasi cake yang dieksperimenkan memberi perlakuan substitusi $100 \%$ tepung terigu dengan tepung singkong pada 8 jenis cake, yaitu pound cake, chiffon cake, bolu kukus, roll cake, sponge cake, brownies, fruit cake dan rainbow cake.

Teknik pengulangan dalam membuat setiap jenis cake dengan formula tertentu digunakan sebagai alternatif dari teknik sampling, kemudian analisis data dilakukan secara deskriptif sesuai criteria setiap jenis cake. Hal ini dilakukan karena karakteristik pembuatan variasi cake, cukup sederhana dan eksperimen cake biasanya cukup dengan tiga sampai dengan empat kali pengulangan untuk menguji coba setiap formula cake.

Formula cake yang akan dibuat pada langkah awal (Uji coba I) dengan cara melakukan substitusi terigu sebesar $100 \%$ yang diganti dengan tepung singkong sebagai bahan utama. Tetapi setiap jenis cake terigu tetap dibuat sebagai pengontrol eksperimen cake dari singkong. Jika cake tidak memenuhi kriteria uji kualitas, maka dilakukan langkah kedua (uji coba II) dengan cara melakukan substitusi terigu sebesar $80 \%$ yang diganti dengan tepung singkong. Langkah ketiga dilakukan, jika cake pada uji coba kedua tidak memenuhi kriteria uji kualitas dengan substitusi $60 \%$. Tetapi jika cake pada uji coba ketiga ini tidak memenuhi kriteria uji kualitas, maka berarti substitusi terigu sebagai bahan utama pembuatan cake tidak dapat diganti dengan tepung singkong. Karena substitusi terigu sama dengan atau kurang dari $50 \%$ artinya fungsi tepung terigu tetap sebagai bahan utama.

Pengumpulan data uji kualitas dalam penelitian ini secara organoleptik dengan menggunakan rubrik criteria penilaian sesuai karakteristik setiap jenis cake. Setiap jenis cake memiliki kriteria khusus, sehingga rubrik penilaian kualitas disesuaikan dengan kriteria jenis cake yang akan di uji cobakan tersebut. Data hasil penelitian meliputi rasa, aroma, warna (tingkat 
kecerahan) dan tekstur. Penilaian uji kualitas ini dilakukan oleh panelis terlatih, kemudian dilanjutkan Focus Group Discusion (FGD) untuk menentukan penilaian kualitas setiap jenis cake dari tepung singkong.

Sedangkan kesimetrisan cake, volume (tinggi cake) dan kelembaban permukaan cake termasuk kualitas lainnya, sehingga analisis data dilakukan dengan menginterpretasi seluruh informasi yang ada atau dikenal dengan interpretative (Patton, 1990). Analisis tersebut digunakan untuk membangun makna dari fakta-fakta yang ada sehingga keberadaan objek dapat dipahami dengan baik. Hasil interpretasi disajikan secara deskriptif sesuai dengan fokus penelitian meliputi pemaparan fakta dan makna yang dibangun secara terintegrasi. Dengan demikian tingkat kualitas cake ditentukan berdasarkan kombinasi dari keenam penilaian aspek di atas.

\section{HASIL DAN PEMBAHASAN}

Proses pengolahan tepung singkong dilakukan dengan prosedur yang sederhana yaitu mengolah singkong terlebih dahulu menjadi cacah, kemudian dihaluskan menjadi tepung singkong. Perlakuan dalam eksperimen ini dengan mengganti $100 \%$ bahan utama cake, yaitu menggunakan 100\% tepung singkong. Uji coba formula awal dengan $100 \%$ terigu dilakukan sebagai kontrol kualitas cake singkong. Analisis data kualitas cake yang diperoleh dalam penelitian ini meliputi empat aspek kriteria cake yang dibandingkan dalam bentuk grafik yaitu kualitas rasa, kualitas aroma, kualitas warna dan kualitas tekstur. Perbedaan pada proses pengovenan pada semua variasi cake singkong memerlukan waktu lebih lama dari pada cake terigu. Selisih waktu pengovenan pada variasi cake singkong sekitar 15 menit sampai dengan 20 menit, untuk memperoleh kematangan cake singkong. Hal ini disebabkan fungsi protein mengikat kerangka cake, pada tepung singkong jumlah protein lebih sedikit dari protein pada tepung terigu, sehingga cake singkong memiliki volume (tinggi cake) lebih rendah dan cake singkong menjadi lebih padat dibandingkan cake dari terigu. Hal ini yang menyebabkan proses pengovenan menjadi lebih lama.

Hasil Penelitian ini disajikan dalam bentuk Grafik untuk kualitas rasa, kualitas aroma, kualitas warna dan kualitas tekstur, yang diuraikan sebagai berikut:

Grafik 1. Data Kualitas Rasa Variasi Cake Singkong dengan substitusi $100 \%$ bahan utama. Hasil penelitian pada kriteria rasa memperoleh data kualitas rasa dengan tingkat kemanisan yang sempurna dan rasa khas singkong pada setiap variasi cake. Kualitas rasa pada variasi cake singkong hanya sedikit terdapat perbedaan pada setiap cake singkong, artinya kualitas rasa manis sempurna dan sangat terasa khas singkong. Secara jelas kualitas rasa pada masingmasing cake singkong: pound cake, chiffon cake, bolu kukus, roll cake, sponge cake, brownies, fruit cake dan rainbow cake, sebagai berikut: 


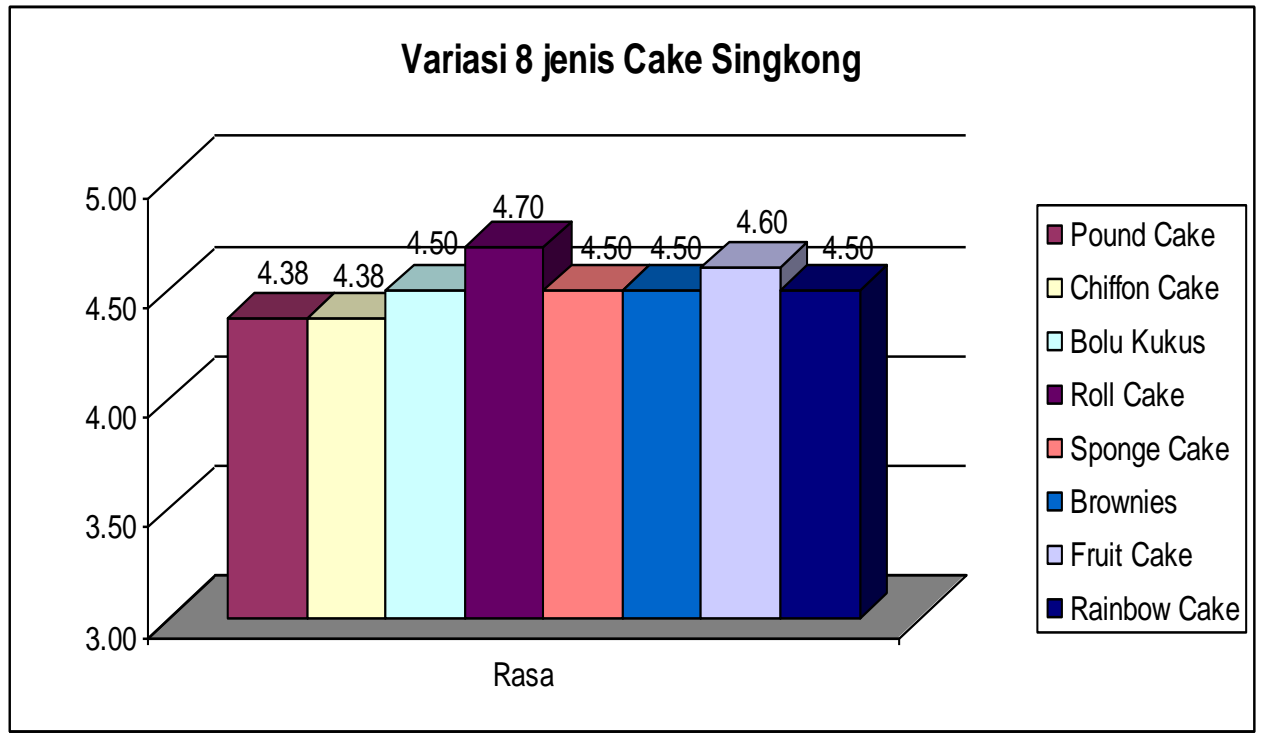

Grafik 1. Data Kualitas Rasa Variasi Cake Singkong

Sedangkan pada Grafik 2. Data Kualitas Aroma Variasi Cake Singkong dengan substitusi $100 \%$ bahan utama. Hasil penelitian pada kriteria aroma memperoleh data kualitas aroma cake dan aroma khas singkong dari pound cake, chiffon cake, bolu kukus, roll cake, sponge cake, brownies, fruit cake dan rainbow cake, sebagai berikut:

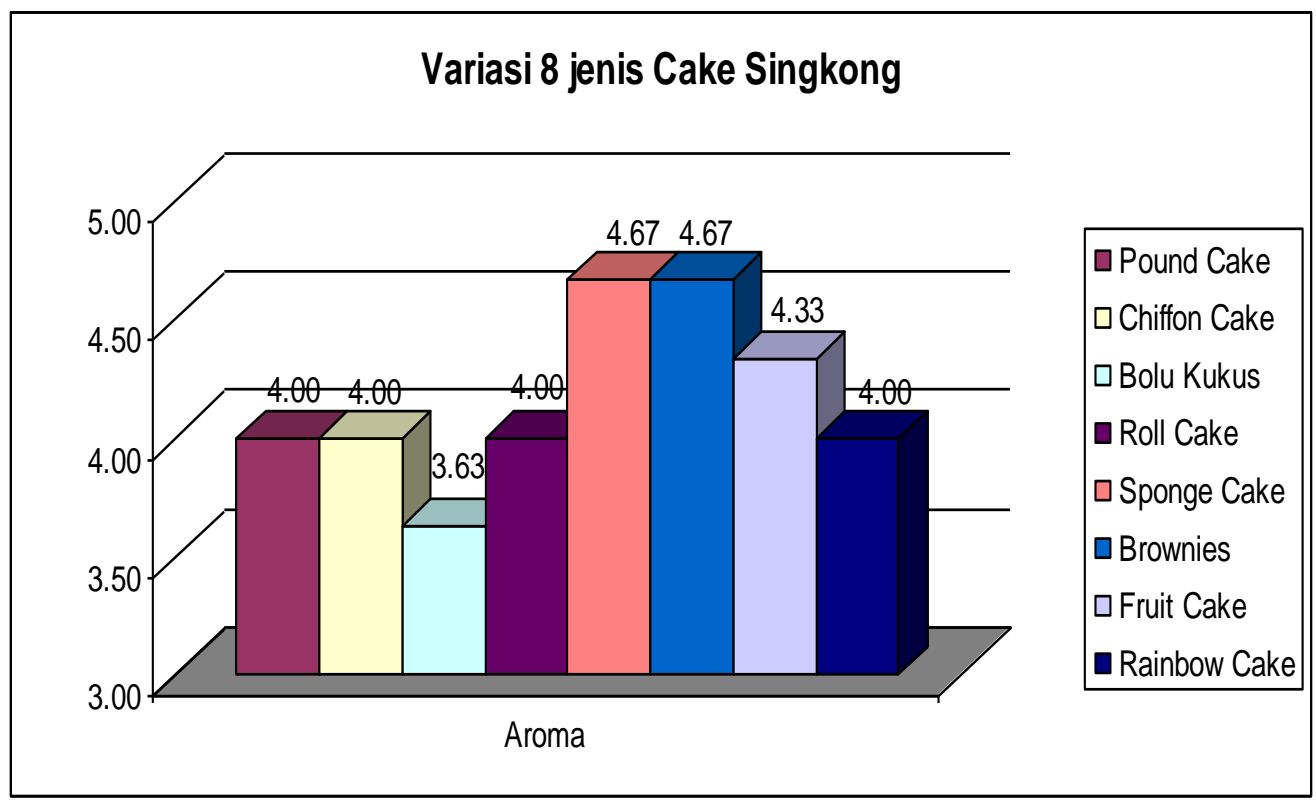

Grafik 2. Data Kualitas Aroma Variasi Cake Singkong 
Kualitas aroma pada variasi cake singkong adalah normal artinya aroma cake lebih dominan dari pada aroma khas singkong. Sedangkan pada bolu kukus paling rendah nilai aromanya, karena aroma khas singkong lebih dominan dari pada aroma cake.

Pada Grafik 3. Data Kualitas Warna Variasi Cake Singkong dengan substitusi $100 \%$ bahan utama. Hasil penelitian menjelaskan tingkat kecerahan warna dari variasi 8 jenis cake singkong dalam bentuk grafik. Maksudnya kualitas warna dilihat dari tingkat kecerahan cake. Pada pound cake singkong dan sponge cake singkong memiliki warna cerah, sedangkan pada chiffon cake singkong, bolu kukus singkong dan roll cake singkong memiliki warna sangat cerah. Tingkat kecerahan warna pada brownies singkong dipengaruhi oleh banyaknya coklat yang digunakan, sehingga warna coklat sangat dominan dan pada fruit cake singkong dipengaruhi banyaknya buah-buahan dan kacang tanah sebagai isi dari fruit cake singkong tersebut, sehingga warna kurang cerah. Tetapi pada rainbow cake, warna nampak tidak cerah dan sedikit agak kusam. Hal ini karena pencampuran warna bahan utama tepung singkong adalah putih susu agak kekuningan dengan cairan pewarna makanan. Data kualitas warna, sebagai berikut:

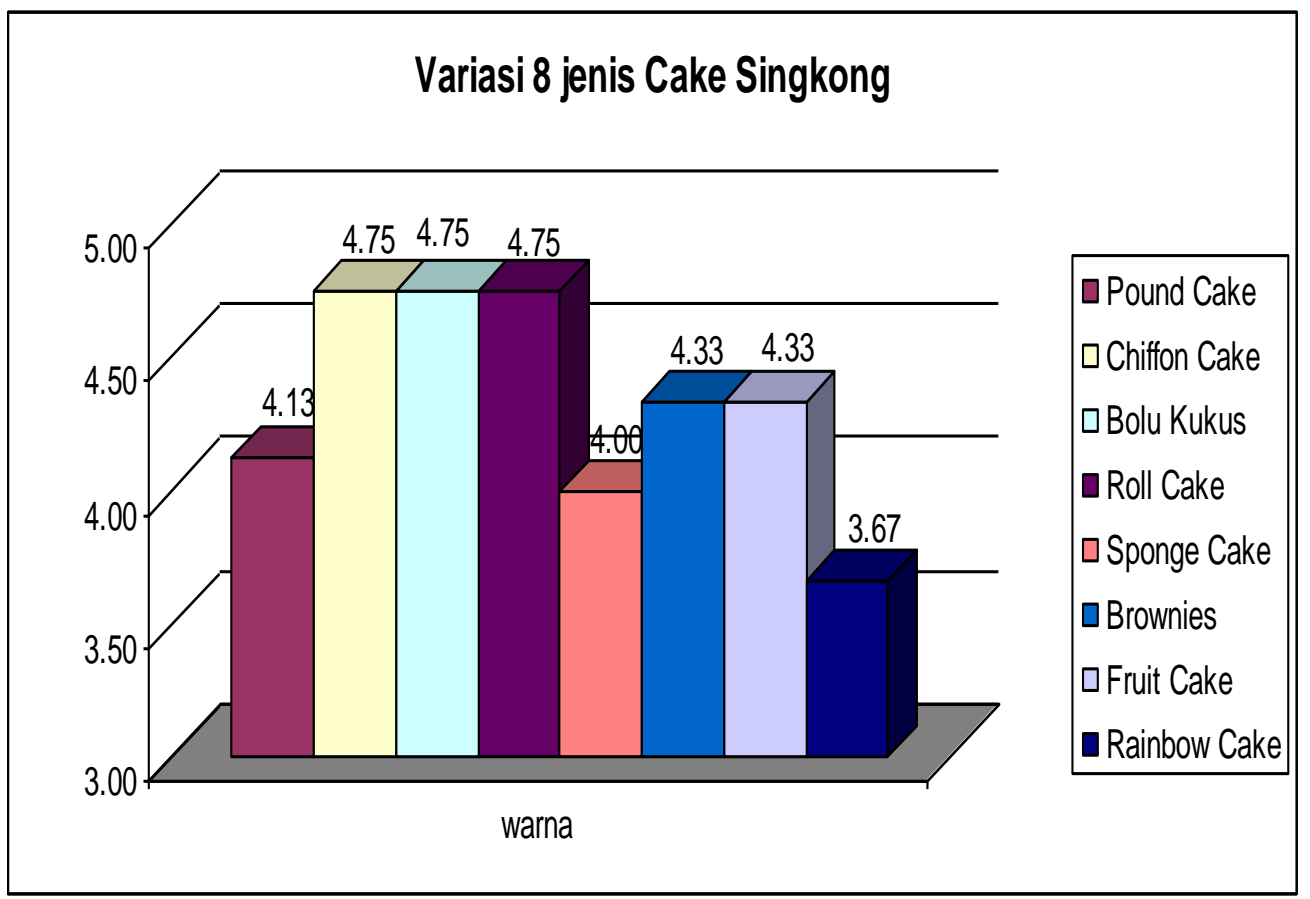

Grafik 3. Data Kualitas Warna Variasi Cake Singkong

Sedangkan pada Grafik 4. Data Kualitas Tekstur Variasi Cake Singkong dengan substitusi $100 \%$ bahan utama. Hasil penelitian pada kriteria tekstur 
merupakan data kualitas tekstur dari variasi cake singkong yang menjelaskan kerataan butiran dan rongga/pori-pori cake, sebagai berikut:

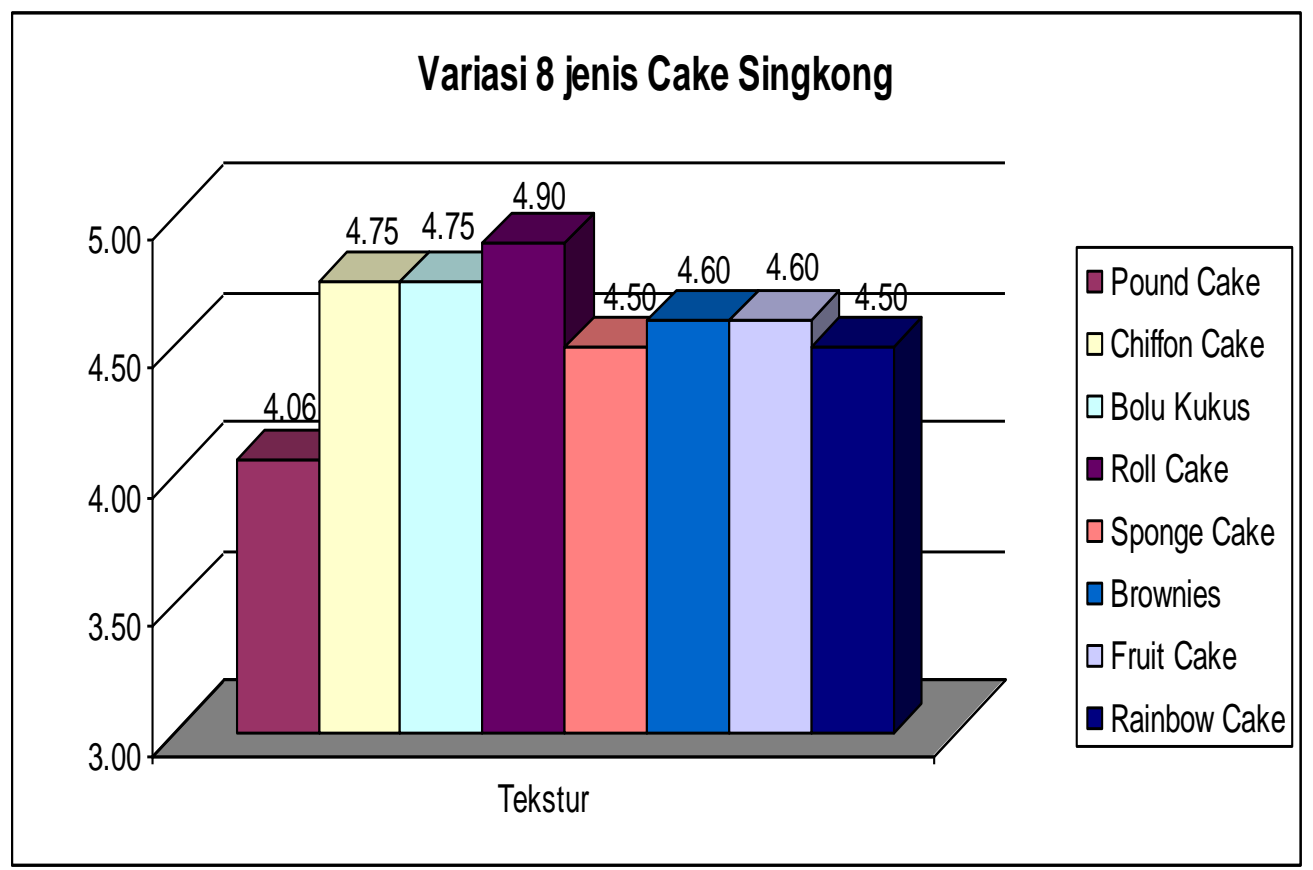

Grafik 4. Data Kualitas Tekstur Variasi Cake Singkong

Kualitas tekstur meliputi kriteria butiran halus (tidak bergumpal) dan poripori merata. Pada pound cake singkong, butiran halus dan pori-pori rata, sedangkan pada cake singkong lainnya butiran sangat halus dan pori-pori sangat rata. Dari semua variasi cake singkong, roll cake singkong memiliki butiran sangat halus dan dan pori-pori sangat rata, sehingga roll cake singkong sangat lembut, karena roll cake singkong menggunakan banyak kuning telur.

Data kualitas lainnya dalam penelitian ini yaitu kesimetrisan, volume (tinggi cake) dan kelembaban permukaan cake, dijelaskan secara deskriptif sebagai berikut:
1. Pound cake singkong adalah cake yang padat dan tinggi karbohidrat dari banyaknya kandungan gula, lemak dan tepung singkong.

Kualitas lainnya dengan kriteria (a) kesimetrisan pound cake sesuai kriteria dengan bagian tengah lebih tinggi dari pada bagian sisinya yang mengenai loyang (b) volume diukur tinggi cake mencapai $\pm 5,5 \mathrm{~cm}$ pada bagian tengah cake, sedangkan tinggi pada bagiam pinggir lebih rendah. Pound cake singkong lebih padat jika dibandingkan cake singkong lainnya. (c) permukaan cake lembab/ berminyak, halus, dan sedikit pecah pada permukaan Pound cake singkong. Pound cake singkong mencapai nilai kualitas sempurna (mendekati kualitas Pound cake terigu) 
pada $80 \%$ substitusi bahan utama, artinya kualitas Pound cake singkong
$100 \%$ lebih rendah dibandingkan kualitas Pound cake singkong $80 \%$.

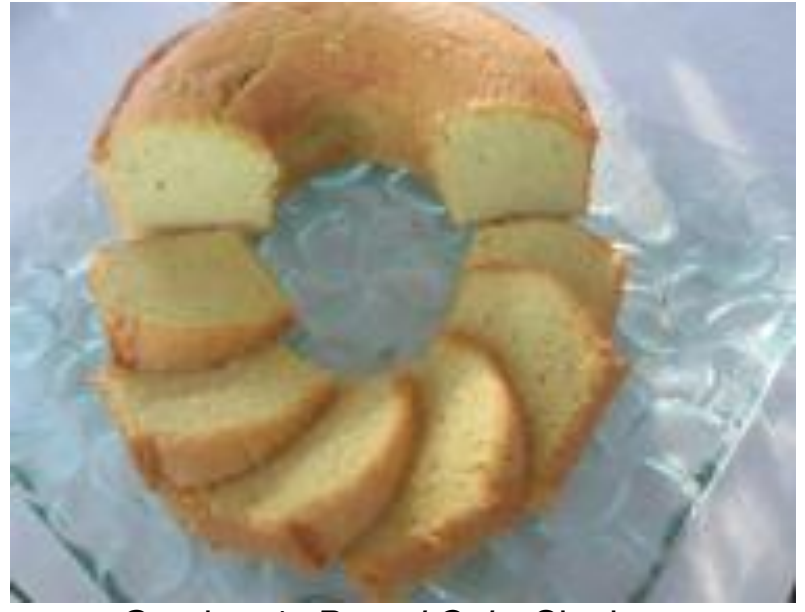

Gambar 1. Pound Cake Singkong

2. Chiffon Cake Singkong adalah cake ringan dan lembut dengan rasa manis dan gurih, karena menggunakan minyak goreng dan santan sebagai lemak cake, adapun kualitas lainnya (a) kesimetrisan cake sesuai dengan kriteria dengan semua bagian sama tinggi (b) volume diukur dengan tinggi cake mencapai \pm 7 $\mathrm{cm}$ (c) permukaan cake lembab/berminyak, empuk dan halus.

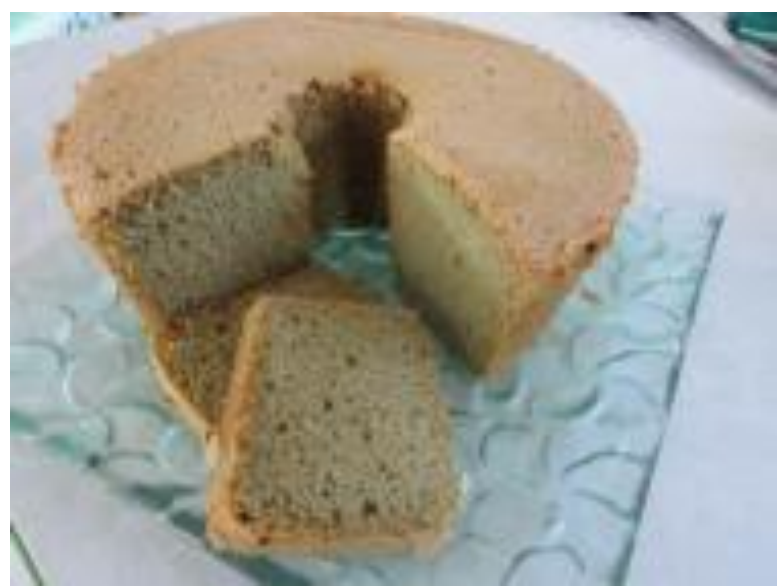

Gambar 2. Chiffon Cake Singkong

3. Bolu Kukus Singkong adalah cake yang dikukus dan berlapis dengan 3 warna, terasa manis dan empuk, mengembang karena menggunakan air soda dan telur, kualitas lainnya (a) kesimetrisan cake pada semua bagian 
persegi empat yang sama tingginya (b) volume diukur dengan tinggi cake mencapai $\pm 5 \mathrm{~cm}$ (c) permukaan cake lembab/berminyak, lembut dan halus. Bolu kukus singkong mencapai nilai kualitas sempurna (mendekati kualitas
Bolu kukus terigu) pada $80 \%$ substitusi bahan utama, artinya kualitas Bolu kukus singkong $100 \%$ lebih rendah dibandingkan kualitas bolu kukus singkong $80 \%$.
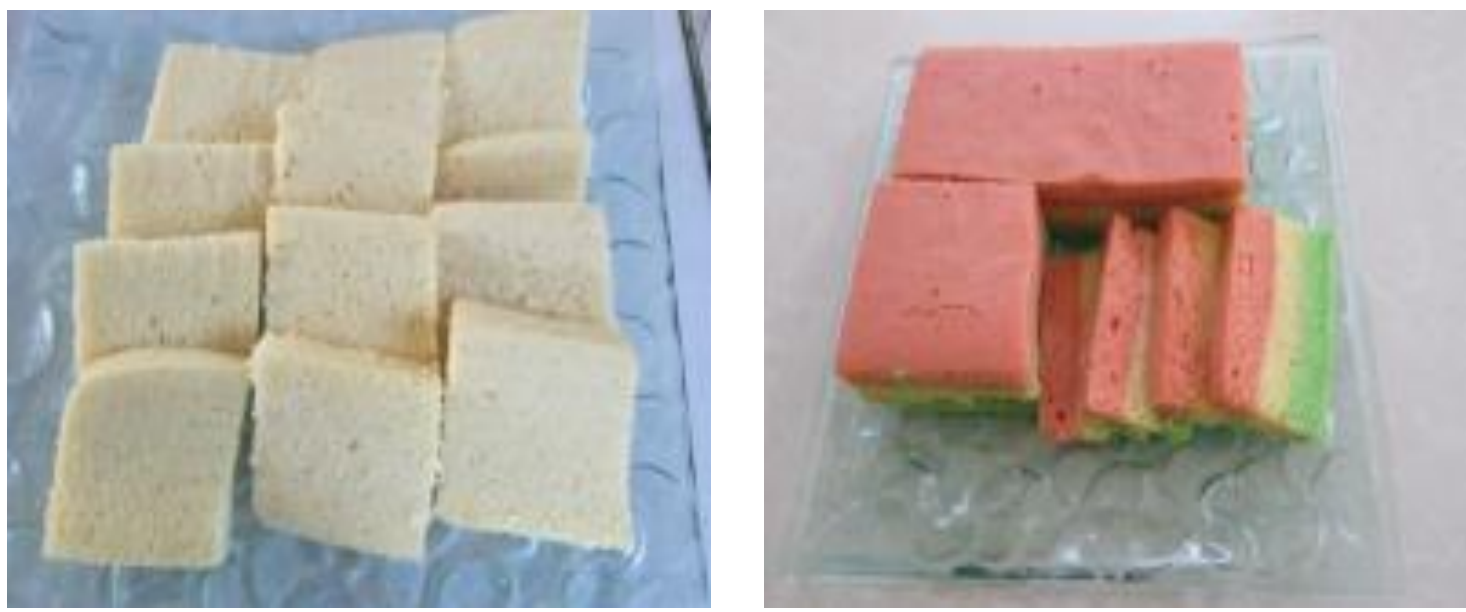

Gambar 3. Bolu kukus Singkong (tanpa pewarna dan menggunakan pewarna)

4. Roll Cake Singkong adalah cake padat yang lembut digulung dengan ketebalannya $1 \mathrm{~cm}$, banyak mengandung gula dan kuning telur, diberi lapisan berbagai macam, kualitas lainnya (a) kesimetrisan cake pada semua sisi sama tingginya (b) volume diukur dengan diameter cake mencapai \pm 7 $\mathrm{cm}$ (c) permukaan cake lembab/berminyak, tidak lengket, sangat lembut dan halus.

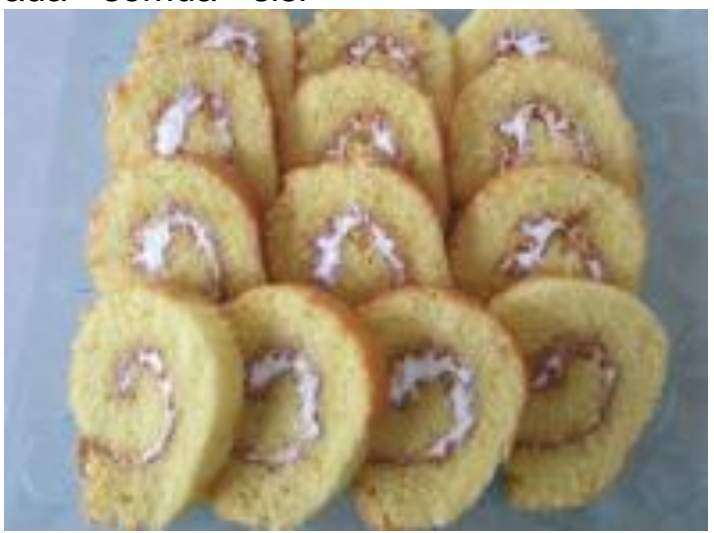

Gambar 4. Roll Cake Singkong 
5. Sponge cake singkong adalah cake yang dihias (decorating cake) dengan adonan dasar cair yang terbuat dari campuran gula, telur dan tepung singkong. Kualitas lainnya (a) kesimetrisan cake pada semua sisi sama tingginya dan merata (b) volume diukur dengan tinggi cake mencapai \pm 5 cm (c) permukaan cake lembab, tidak lengket, terdapat lubang-lubang kecil dan lembut. Sponge cake singkong mencapai nilai kualitas sempurna (mendekati kualitas Sponge cake terigu) pada $80 \%$ substitusi bahan utama, artinya kualitas Sponge cake singkong $100 \%$ lebih rendah dibandingkan kualitas Sponge cake singkong $80 \%$.

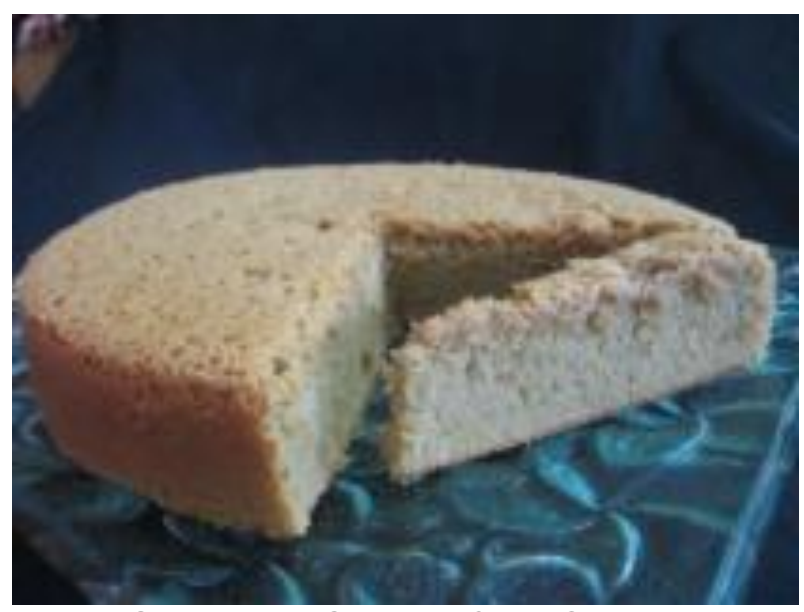

Gambar 5. Sponge Cake Singkong

6. Brownies singkong adalah cake bantat yang padat yang dioven, berwarna coklat tua dan tinggi kalori, dengan rasa manis dan coklat yang kuat. Adapun kualitas lainnya dengan kriteria (a) kesimetrisan pada semua sisi memiliki tinggi yang sama dan merata (b) volume diukur dengan tinggi brownies mencapai $\pm 4 \mathrm{~cm}$ (c) permukaan cake berminyak, lembut, halus dan permukaannya mudah pecahpecah. 

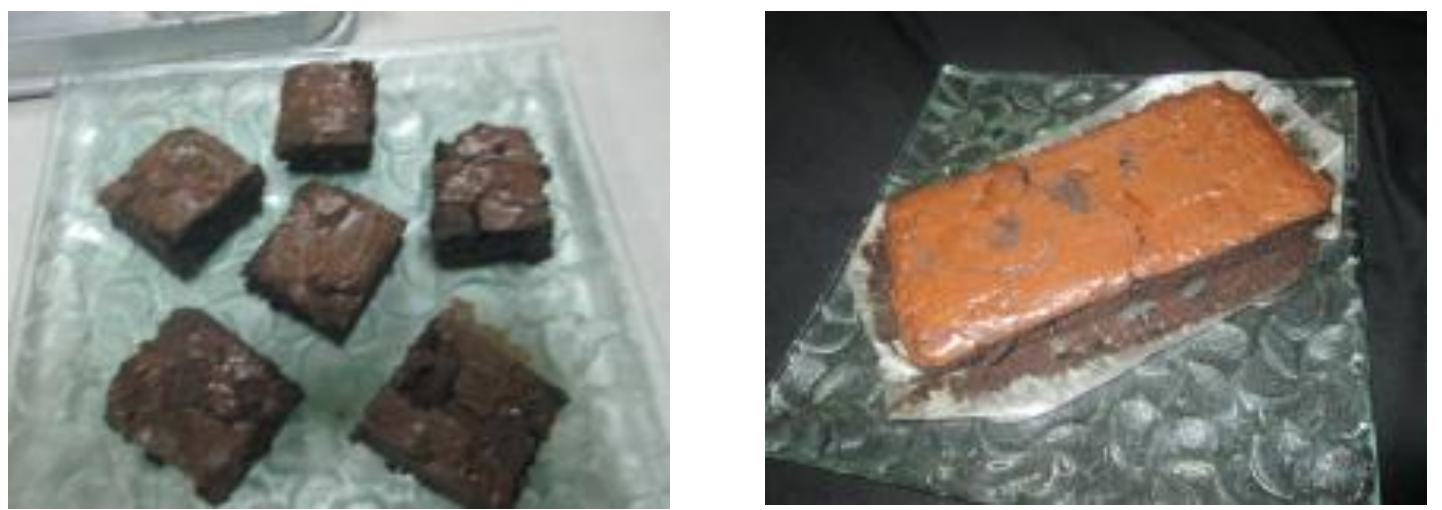

Gambar 6. Brownies Singkong (oven)

7. Fruit Cake singkong merupakan cake yang padat, karena kaya dengan buahbuahan lokal (salak, anggur bali, strawberry, sukade, kismis) dan kacang tanah, cake terbuat dari adonan kental dengan bahan tepung, gula, telur dan lemak, sehingga dimasak dengan api kecil dalam waktu lama. Adapun kualitas lainnya dengan kriteria (a) kesimetrisan pada semua sisi memiliki tinggi yang sama dan merata (b) volume diukur dengan tinggi cake mencapai $\pm 6 \mathrm{~cm}$ (c) permukaan cake berminyak, lembut, halus dan tidak pecah-pecah.

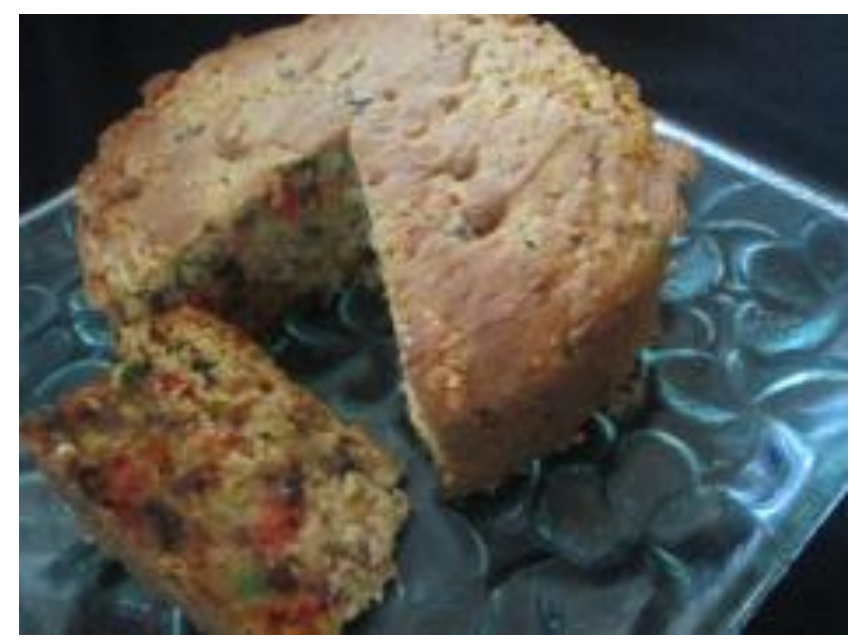

Gambar 7. Fruit Cake Singkong 
8. Rainbow cake singkong adalah cake tipis dengan tebal lapisan $1 \mathrm{~cm}$ (sedikit mengembang) berwarna-warni yang disusun dan dilapisi cream, sehingga ketebalannya mencapai $8 \mathrm{~cm}$. Adapun kualitas lainnya dengan kriteria (a) kesimetrisan pada semua sisi memiliki tinggi yang sama dan merata (b) volume diukur dengan tinggi cake mencapai \pm 8 cm (c) permukaan cake lembab, lembut dan sedikit rapuh (d) Jika dibandingkan cake singkong lainnya, pori-pori rainbow cake singkong lebih besar pada bagian atas setiap lapisan cake tersebut.

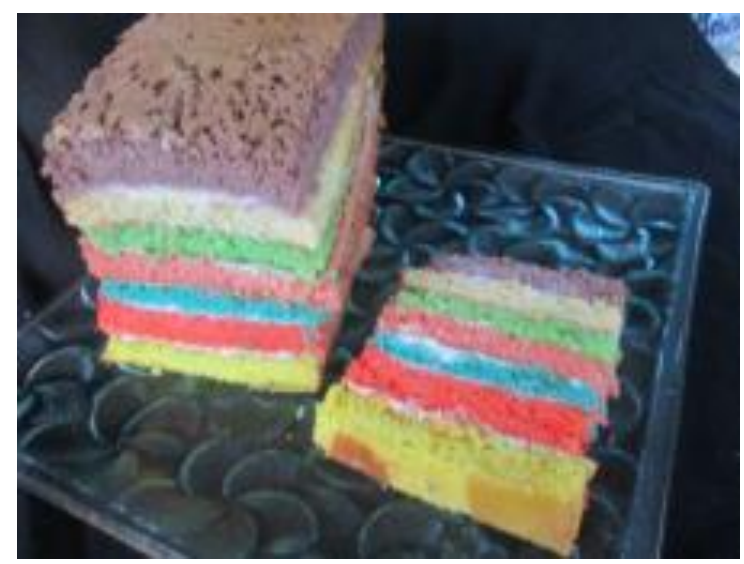

Gambar 8. Rainbow Cake Singkong

\section{PENUTUP}

Kesimpulan dalam penelitian ini adalah kemampuan diversifikasi tepung singkong sebagai substitusi $100 \%$ terigu untuk memperoleh variasi 8 jenis cake singkong, sebagai berikut:

1. Kualitas pound cake singkong mendekati kriteria pound cake terigu,

2. Kualitas chiffon cake singkong sangat sesuai dengan kriteria kualitas chiffon cake terigu.

3. Kualitas bolu kukus singkong sesuai dengan kriteria kualitas bolu kukus terigu.

4. Kualitas roll cake singkong sangat sesuai dengan kriteria kualitas roll cake terigu.

5. Kualitas sponge cake singkong mendekati kriteria kualitas roll cake terigu.
6. Kualitas fruit cake singkong sangat sesuai dengan kriteria kualitas roll cake terigu.

7. Kualitas brownies singkong sangat sesuai dengan kriteria kualitas roll cake terigu.

8. Kualitas rainbow cake singkong sesuai dengan kriteria kualitas roll cake terigu, kecuali warna kurang cerah.

Artinya tepung singkong dapat digunakan sebagai substitusi terigu $100 \%$ untuk membuat variasi cake singkong yang berkualitas sesuai dengan kriteria cake, meskipun memerlukan waktu lebih lama dalam proses pengovenan. Pada beberapa cake singkong seperti pound cake, bolu kukus dan sponge cake, substitusi sebaiknya menggunakan $80 \%$ bahan

Jurnal IImu Sosial dan Humaniora|729 
utama tepung singkong. Sedangkan hasil penelitian pada chiffon cake, roll cake, brownies, fruit cake dan rainbow cake dapat menggunakan substitusi bahan utama dengan $100 \%$ tepung singkong.

Walaupun penelitian ini berhasil memperoleh variasi 8 jenis cake singkong, tetapi kendala pemanfaatan tepung singkong belum diketahui masyarakat, sehingga perlu promosi agar masyarakat memanfaatkan tepung singkong sebagai bahan baku lokal pengganti tepung terigu.

\section{DAFTAR PUSTAKA}

Agrobusiness, Daily News, February 6 2013, Berita: Bahan Pangan Yang Terus Di Impor, Detik.com. Akses 1/9/2014

Arisman.M.B, 2007, Gizi dalam Daur Kehidupan, Buku Ajar Ilmu Gizi, Jakarta: Penerbit Kedokteran EGC.

Direktorat Gizi, DepKes, 1989, Daftar Komposisi Bahan Makanan, 1989, Jakarta, Penerbit Bhratara Niaga Media.
Green Trust Magazine (Majalah Petani), 2010, Artikel Pertanian dalam Berita: Kita harus Peduli terhadap Ketahanan Pangan, Volume 02 Juni - Agustus 2010 ISSN 0216-7883, DGIS Belanda.

Lies Suprapti, M. 2006. Teknologi Tepat Guna: Tepung Kasava Pembuatan dan Pemanfaatannya. Yogyakarta. Penerbit: Kanisius.

--------. 2007. Teknologi Pengolahan Pangan: Tepung Ubi Jalar Pembuatan dan Pemanfaatannya. Yogyakarta. Penerbit: Kanisius.

Marsiti, Cokorda Istri Raka, 2005, Patiseri I, Diktat Kuliah Jurusan PKK-Tata Boga, IKIP Negeri Singaraja

Pusat Penyuluhan Kesehatan Masyarakat, 2006, Pedoman Umum Pengembangan Konsumsi Pangan, Jakarta: Dep. Kes. R.I. 